\title{
Integrated Solid Waste Management Under Global Warming
}

\author{
Xianlai Zeng ${ }^{*}$, Qina Sun, Baoquan Huo, Hongfen Wan, and Changyong Jing \\ Laboratory of Solid Waste Reclamation, Department of Environmental Engineering, Environmental Management
College of China, Qinhuangdao, 066004, P.R. China
}

Qinhuangdao Park, Foxconn Technology Group, Qinhuangdao, P.R.China

\begin{abstract}
Global warming is the hottest global concern, and may be one of the greatest threats facing the world. Attention to global warming has been paid in recent 30 years, and become stronger with advent of post-Kyoto era. On the other hand, increasing solid waste from rapid urbanization and economic growth has plagued the government for a long time. Conventional integrated solid waste management led to greenhouse gases emission during the life cycle of solid waste, contributing to global warming. Concern for the environment and future generations is leading us to shift the focus from waste management to resource management. So a new hierarchy of integrated solid waste management is also addressed in detail, which will lead to idea switching on manufacturing enterprises and managing government.
\end{abstract}

Keywords: Solid waste, global warming, greenhouse gases, management hierarchy, life cycle.

\section{INTRODUCTION}

In the recent years, global warming, driven by the rising of greenhouse gases (GHGs) in the Earth's atmosphere, is now a highly concerned issue as it could cause many changes at the global scale, especially climate pattern, which is now recognized as a serious threat to human civilization. Solid waste, another issue of global significance is an important source to generate GHGs. To reduce GHGs emission from solid waste, conventional solid waste management should be converted as resource management. Thus this article will review attention history of global warming, introduce how solid waste contributes to GHGs emission during its life cycle, and construct a new hierarchy of integrated solid waste management.

\section{GLOBAL WARMING AND SOLID WASTE MANAGEMENT}

\section{Global Warming}

Global warming or climate change is not a new phenomenon in the Earth's history. The geological record shows that when viewed over a time scale of thousands of years the climate is in a state of more or less continual change with major ice ages occurring approximately every 100,000 years. But in recent one hundred years after the first Industrial Revolution and especial decades, the global temperate do arise quickly shown in Fig. (1). Accompanying the Industrial Revolution was a massive growth in energy consumption, largely through the burning of coal, a fossil fuel. The Industrial Revolution marked the beginning of the period during which mankind began substantially altering the composition of the atmosphere.

Global warming has led to major environmental changes such as, (1) rising sea levels that may flood coastal and river

*Address correspondence to this author at the Environmental Management College of China, 066004 Qinhuangdao, China; Tel/Fax: +863355315772; E-mail: xianlzeng@hotmail.com delta communities; (2) shrinking mountain glaciers and reduced snow cover that may diminish fresh water resources; (3) the spread of infectious diseases and increased heatrelated mortality; (4) possible loss in biological diversity and other impacts on ecosystems; and (5) agricultural shifts such as impacts on crop yields and productivity [1]. Although reliably detecting the trends in climate due to natural variability is difficult, the most accepted current projections suggest that the rate of climate change attributable to GHGs will far exceed any natural climate changes that have occurred during the last 1,000 years.

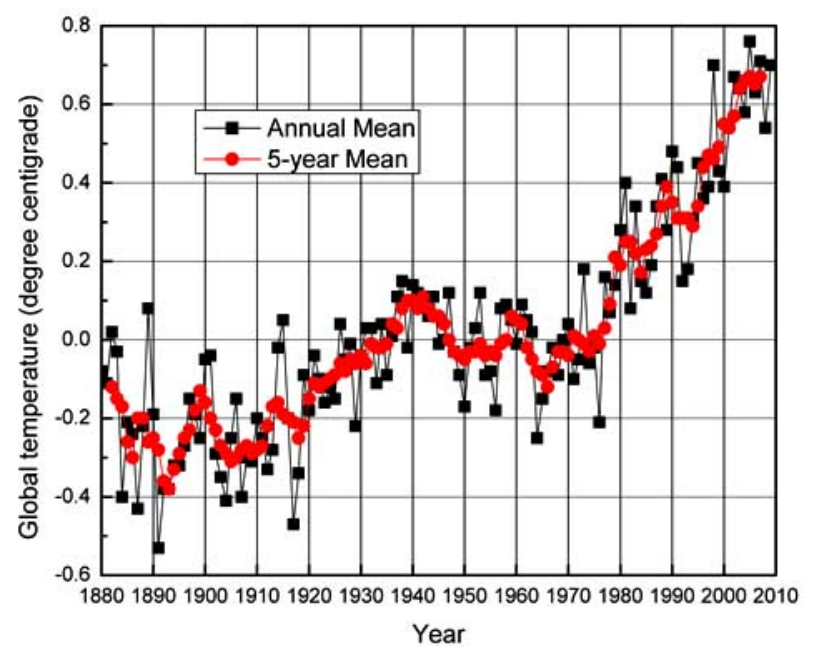

Fig. (1). Global temperature variation from 1880 to 2009 .

\section{Attention History}

Continually increasing global temperature motivated people to care for global warming in recent 30 years. Political and public debate continued regarding global warming, and what actions to take in response. Most national governments have signed and ratified some agreements aimed at reducing greenhouse gas emissions. Agreements 
and World Environmental Day theme on global warming were showed from 1989 to 2009 in Fig. (2). In retrospect, concern and action have travelled a tortuous road. World Environmental Day theme in 1989 and 1991 pulled the people on global warming. To achieve stabilization of greenhouse gas concentrations in the atmosphere at a level that would prevent dangerous anthropogenic interference with the climate system, Framework Convention on Climate Change was signed by 154 countries in Rio de Janeiro, Brazil, in 1992 and entered into force in March, 1994. Three years later, another important agreement - Kyoto Protocol, was adopted in Kyoto, Japan, on December 11, 1997, which set binding targets for 37 industrialized countries and the European community for reducing GHGs emission under the principle of "common but differentiated responsibilities". Unfortunately, the international agreement entered into force on February 16, 2005. With the advent of expire time of Kyoto Protocol, a new program agreement should be constructed in post-Kyoto era. So World Environmental Day set the themes as "Melting Ice-a Hot Topic?", "Kick the Habit! Towards a Low Carbon Economy", and "Your Planet Needs You-Unite to Combat Climate Change" in 2007, 2008, 2009, respectively. At the same time, Bali Road Map was attained in Indonesia on December 3 to 15, 2007. Aiming at implement Bali Road Map to draft a successive agreement of Kyoto Protocol, more frequent conferences and talks have been hold in recent three years. A latest conference was Copenhagen conference in December, 2009, and reached a controversial agreement - Copenhagen Accord. Unfortunately, the accord was not a mandatory agreement. But it will trigger adaption from all work of our life in the future.

\section{GHGs from Solid Waste}

Global warming is driven by the rising of GHGs, which primarily include water vapor, $\mathrm{CO}_{2}, \mathrm{CH}_{4}$, and nitrous oxide.

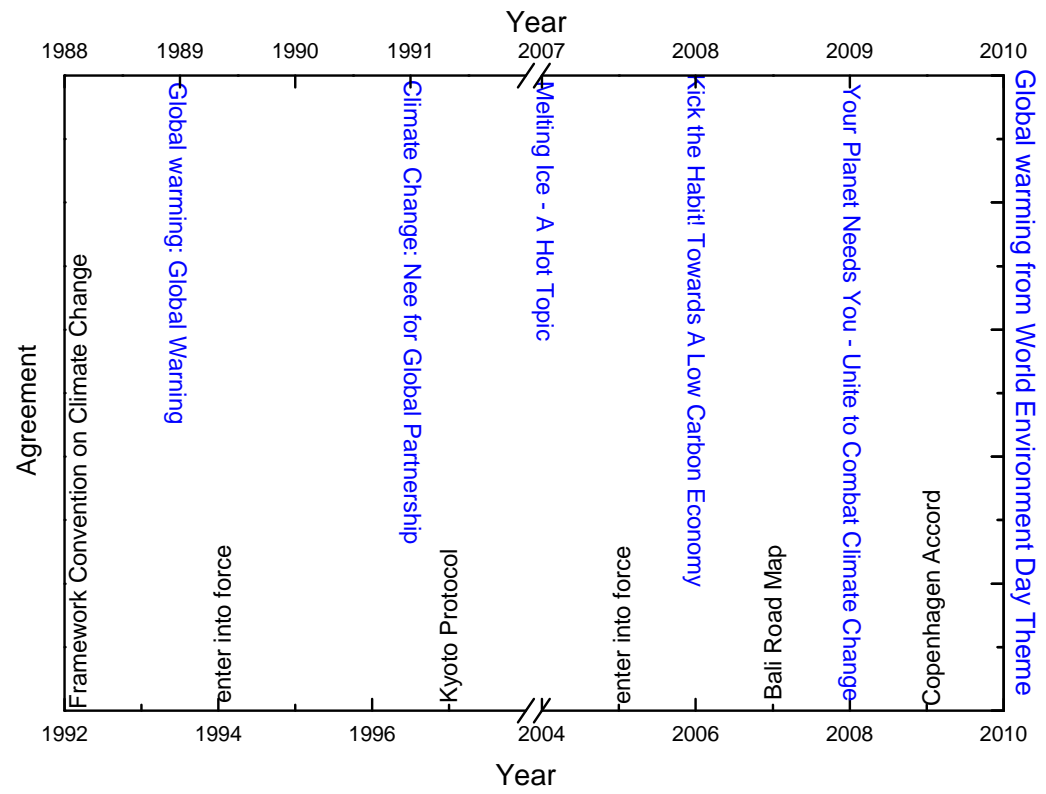

Fig. (2). Agreement and world environmental day theme on global warming in recent 20 years.

Table 1. Direct GWP Values for Selected Well Mixed GHGs for Three Different Time Horizons

\begin{tabular}{|c|c|c|c|c|c|c|}
\hline S. No & GHGs & Radiative Forcing $\left(\mathbf{W} \cdot \mathbf{m}^{-2} \cdot \mathbf{p p b}^{-1}\right)$ & Atmospheric Lifetime (Years) & 20 Year & 100 Year & 500 Year \\
\hline 2 & $\mathrm{CH}_{4}$ & 0.00037 & 12 & 62 & 23 & 7 \\
\hline 3 & $\mathrm{~N}_{2} \mathrm{O}$ & 0.0032 & 114 & 284 & 306 & 161 \\
\hline 5 & $\mathrm{CFC}-12\left(\mathrm{CCl}_{2} \mathrm{~F}_{2}\right)$ & 0.32 & 100 & 10200 & 10600 & 5200 \\
\hline 6 & $\mathrm{HCFC}-22\left(\mathrm{CHClF}_{2}\right)$ & 0.22 & 12 & 5200 & 1900 & 590 \\
\hline 7 & $\mathrm{HFC}-23\left(\mathrm{CF}_{3} \mathrm{H}\right)$ & 0.16 & 257 & 9400 & 12000 & 9900 \\
\hline 8 & HFC-134a $\left(\mathrm{CF}_{3} \mathrm{CFH}_{2}\right)$ & 0.17 & 14 & 3700 & 1500 & 450 \\
\hline
\end{tabular}


To assist policy makers to understand the potential impact on climate of different GHGs, the concept of global warming potential (GWP) has been introduced [2]. GWP values for several long-lived GHGs are listed in Table 1.

GHGs emission is not inevitable during solid waste management process, whose emission accounted for $3.6 \%$ of total annual world GHGs emission, shown in Fig. (3) [3, 4].

In fact, GHGs are discharged during the life cycle of solid waste, which was illustrated in Fig. (4). For many wastes, the materials in municipal solid waste (MSW) represent what is left over after a long series of steps: (1) extraction and processing of raw materials; (2) manufacture of products; (3) transportation of materials and products to markets; (4) use by consumers; and (5) waste management. Virtually every step along this "life cycle" impacts GHGs emissions.

Recycling: When a material is recycled, it is used in place of virgin inputs in the manufacturing process. The avoided GHGs emissions from remanufacture using recycled inputs is calculated as the difference between (1) the GHGs emissions from manufacturing a material from $100 \%$ recycled inputs, and (2) the GHGs emissions from manufacturing an equivalent amount of the material (accounting for loss rates) from 100 percent virgin inputs (including the process of collecting and transporting the recyclables). No GHGs emissions occur at the MSW management stage because the recycled material is diverted from waste management facilities. (If the product made from the recycled material is later composted, combusted, or landfilled, the GHG emissions at that point would be attributed to the product that was made from the recycled material).

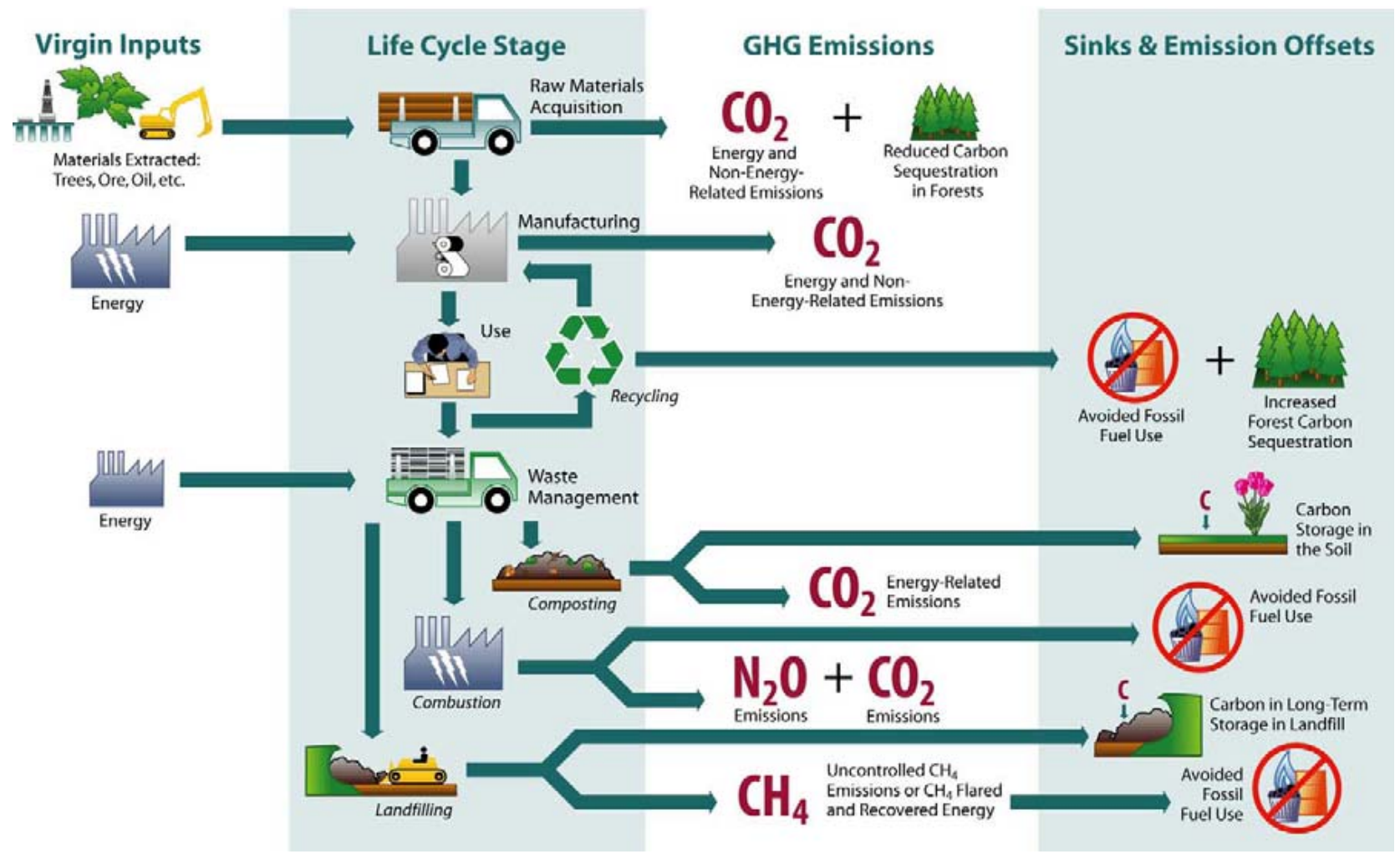

Fig. (4). Diagram of material and energy life-cycle flows and the associated GHGs sources and sinks. 


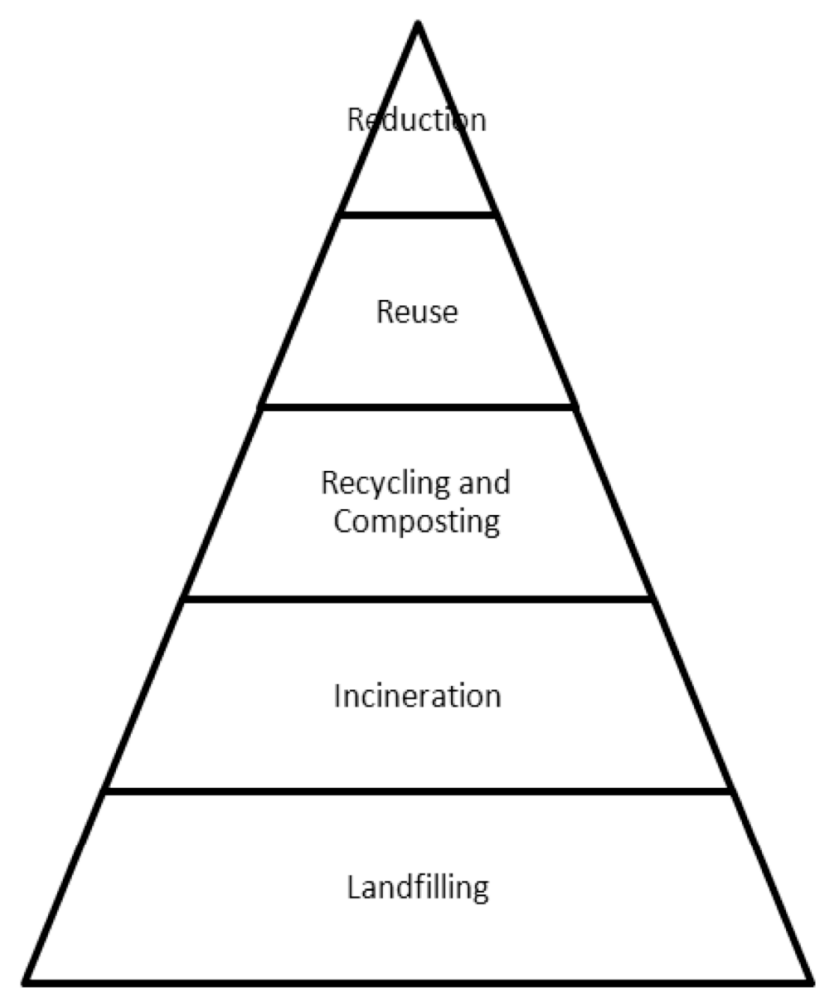

Fig. (5). Conventional hierarchy of integrated solid waste management [8].

Combustion: When waste is combusted, two GHGs are emitted: $\mathrm{CO}_{2}$ and $\mathrm{N}_{2} \mathrm{O}$. Non-biogenic $\mathrm{CO}_{2}$ emitted during combustion is counted toward the GHG emissions associated with combustion, but biogenic $\mathrm{CO}_{2}$ is not. Because most waste combustors produce electricity that substitutes for utility-generated electricity, the net GHGs emissions are calculated by subtracting the utility GHGs emissions avoided from the gross GHGs emissions. Relative GWP is lower for combustion or incineration than composting and landfilling, but the cost is extremely high [5].

Landfilling: When organic waste is deposited in landfills, a product of bacterial decomposition is landfill gas, which is composed of $\mathrm{CH}_{4}$ and $\mathrm{CO}_{2}$ in approximately equal concentrations. Some of organic matter never decomposes at all; instead, it becomes stored carbon. In order to control the emissions of these contaminant gases, installation of gas extraction systems at landfills is required. However, in spite of the technical efforts to minimize landfill gas emissions, a significant amount of non-controlled emissions are released into the atmosphere in the form of non-controlled emissions through landfill surfaces [6]. With combustion of $\mathrm{CH}_{4}$ for energy recovery, credit is given for the electric utility GHG emissions avoided. Regardless of the fate of the $\mathrm{CH}_{4}$, credit is given for the landfill carbon storage associated with landfilling of some organic materials. If $\mathrm{CH}_{4}$ are collected and then flared, it can reduce amounts of GHG emissions by $65 \%$. If $\mathrm{CH}_{4}$ is used for electricity generation, it can lessen amounts of carbon dioxide emission by $69 \%$ [7].

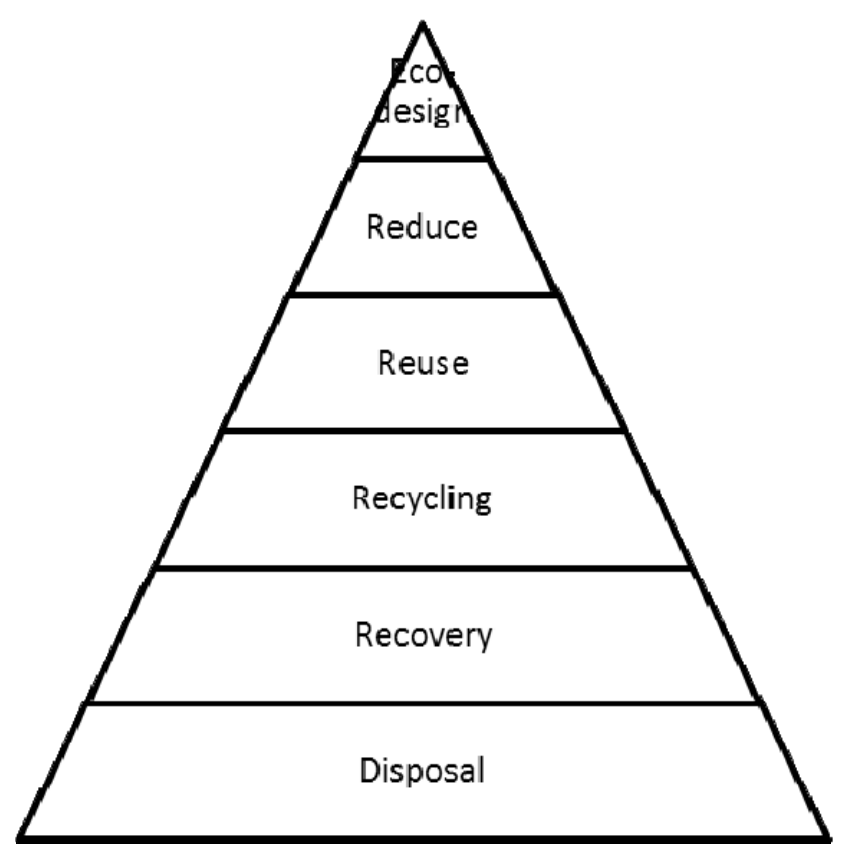

Fig. (6). New hierarchy of integrated solid waste management.

\section{INTEGRATED SOLID WASTE MANAGEMENT UNDER GLOBAL WARMING}

Conventional hierarchy of integrated solid waste management (Fig. 5) was put forward 20 years ago. It set a goal or example for many company or government how to cope with product and solid waste. But unfortunately, the hierarchy could not be put into practice including source sorting and final landfilling in many global areas. The current solid waste landfilling practice is not sustainable with very little consideration given to the application of sustainable development principle during the design, construction and operation stages of landfill development [8].

Concern for the environment and future generations is leading us to shift the focus from waste management to resource management. Under the new background of global warming, conventional hierarchy of integrated solid waste management should be updated. The new hierarchy, shown in in Fig. (6) will contribute to more decline of GHGs emission than the conventional, which is illustrated as follows.

Eco-design: Contrast to conventional product producing, eco-design should be built up and applied into various industries. Eco-design is an approach to design of a product with special consideration for the environmental impacts of the product during its entire lifecycle, and can reduce the stress of downriver on solid waste treatment or disposal. Buildings and products are to be designed with the goal of using fewer chemicals, increased energy efficiency, and reduced footprint.

Reduce: Source reduction, in general, represents an opportunity to reduce GHG emissions in a significant way. For many materials, the reduction in energy-related $\mathrm{CO}_{2}$ 
emissions from the raw material acquisition and manufacturing process, and the absence of emissions from waste management, combine to reduce GHG emissions more than other options.

Recycling: For most materials, recycling has the second lowest GHG emissions. For these materials, recycling reduces energy-related $\mathrm{CO}_{2}$ emissions in the manufacturing process (although not as dramatically as source reduction) and avoids emissions from waste management. Paper recycling increases the sequestration of forest carbon.

Recovery: Recovery of solid waste is reclamation of useful production such as metals and energy, resulting from chemical reaction of solid waste. Composting is a management option for food discards and yard trimmings. The net GHG emissions from composting are lower than landfilling for food discards (composting avoids $\mathrm{CH}_{4}$ emissions), and higher than landfilling for yard trimmings (landfilling is credited with the carbon storage that results from incomplete decomposition of yard trimmings). Overall, given the uncertainty in the analysis, the emission factors for composting or combusting these materials are similar. As solid waste incineration, it could not play the major role for electricity production, but in addition to being a waste management option, could be considered as a complement to conventional power production [9].

Disposal: Unreclaimable waste and residue waste from recycling and recovery will be disposed in landfilling, for instance. Ideally, these wastes cannot discharge GHGs, but store carbon such as carbonate.

In total, new integrated management of solid waste presents many opportunities for GHGs emission reductions. Source reduction and recycling can reduce emissions at the manufacturing stage, increase forest carbon storage, and avoid landfill methane emissions. Combustion of waste allows energy recovery to displace fossil fuel-generated electricity from utilities, thus reducing greenhouse gas emissions from the utility sector and landfill methane emissions. Diverting organic materials from landfills also reduces $\mathrm{CH}_{4}$ emissions.

\section{CONCLUSION}

Global warming has been paid more attention in the recent ten years. How to decline global warming in postKyoto ear is becoming a global concern, not only for developed countries, but also for developing counties. And on the other hand, improper solid waste management contributes to $3.6 \%$ of total GHGs emission, intensifying global warming. A new concept hierarchy of integrated solid waste management was carried out, will decrease GHGs emission in greater degree. The new concept hierarchy will strike enterprise and government to revise the production process or job content. For waste or product, among the efforts to slow the potential for global warming are measures to reduce emissions of $\mathrm{CO}_{2}$ from energy use of solid waste transport, decrease emissions of methane $\mathrm{CH}_{4}$ and other non$\mathrm{CO}_{2}$ GHGs from anaerobic landfilling, and eco-design resource product.

\section{ACKNOWLEDGEMENTS}

The financial support from Foxconn technology group is gratefully acknowledged. And we gratefully acknowledge the three referees of the article.

\section{REFERENCES}

[1] J. J. McCarthy, O. F. Canziani, N. A. Leary, D. J. Dokken, and K S. White, "Climate Change 2001: Impacts, Adaptation and Vulnerability," IPCC, Cambridge University Press, pp. 9-13, 2001.

[2] T. J. Wallington, J. Srinvasan, O. J. Nielsen, and E. J. Highwood, "Greenhouse gases and global warming, in environmental and ecological chemistry", A. Sabljic, Ed. in Encyclopedia of Life Support Systems (EOLSS), Developed under the Auspices of the UNESCO, Eolss Publishers, Oxford, UK, 2004. Available at: http://www.eolss.net.

[3] T. C. Chen, and C. F. Lin, "Greenhouse gases emissions from waste management practices using Life Cycle Inventory model”, $J$. Hazard. Mater., vol. 155, pp. 23-31, January 2008.

[4] World Resources Institute, Climate Analysis Indicator Tool (CAIT), "Navigating the Numbers: Greenhouse Gas Data and International Climate Policy", Intergovernmental Panel on Climate Change, 1996 (data for 2000), [online]. Available: http://pdf.wri. org/navigating_numbers.pdf [Accessed: Dec 10, 2009].

[5] M. N. Hassan, M. Awang, T. L. Chong, Z. Zakaria, L. B. Lay, N. Yusoff, and H. Sino, "The application of an life cycle inventory (LCI) model for solid waste disposal systems in malaysia", Int. J. Life Cycle Assess., vol. 4, pp. 188-190, March 1999.

[6] D. Nolasco, N. M. Fernández, H. de P. Carmona, G. Padilla, G.Melian, P. A. H. Perez, and N. Perez, "Non-controlled $\mathrm{CO}_{2}$ and $\mathrm{CH}_{4}$ emission from landfills: a useful parameter to evaluate landfill gas extraction efficiency", American Geophysical Union, Fall Meeting, 2009

[7] C. Pharino, and B. Jaranasakasakul, CDM: A mechanism to promote solid waste management efficiency and GHG reductions in Thailand. Joint actions on Climate Change, Aalborg, North Denmark, 2009, [online]. Available: http://gin.confex.com/gin/ 2009/webprogram/Paper2439.html [Accessed: Jan 1, 2010].

[8] J. P. A. Hiettiaratchi, O. D. Hurtado, C. Hunte, J. Hundal, C. Colbryn, and S. Smith, "The Calgary biocell: A case study in sustainable solid waste management", In proceeding of the international conference on sustainable solid waste management, Chennai, India, pp.421-428, September 2007.

[9] C. Liamsanguan, and S. H. Gheewala, "Environmental assessment of energy production from municipal solid waste incineration", Int. J. Life Cycle Assess., vol. 12, pp. 529-536, August 2007. 